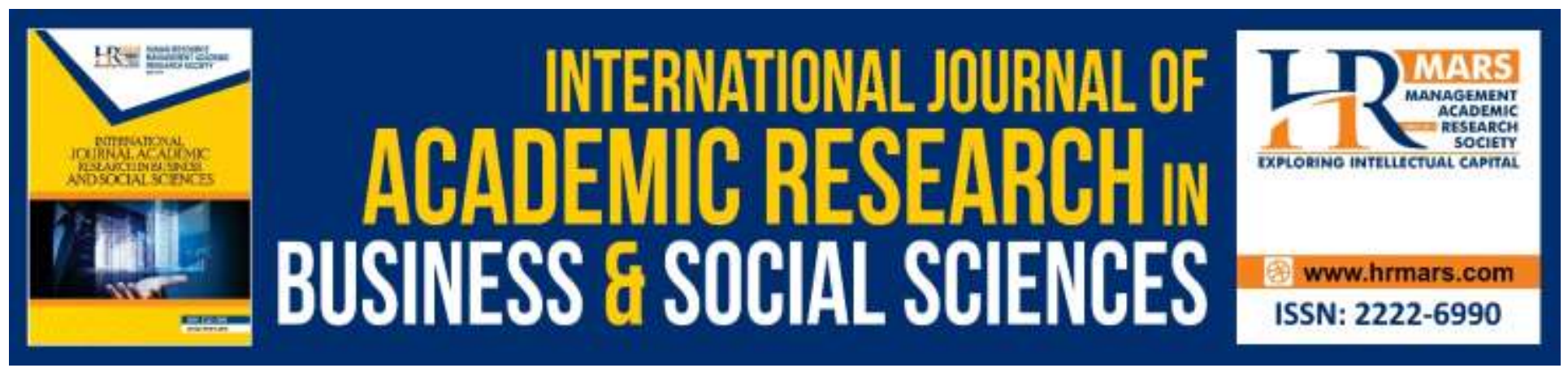

\title{
Role and Contribution of Malay Women's in Malaysia: An Overview
}

\author{
Nang Naemah Nik Dahalan, Nor Adina Abdul Kadir, Mohd Farhan Abd \\ Rahman
}

To Link this Article: http://dx.doi.org/10.6007/IJARBSS/v10-i6/7268

DOI:10.6007/IJARBSS/v10-i6/7268

Received: 07 April 2020, Revised: 19 May 2020, Accepted: 29 May 2020

Published Online: 06 June 2020

In-Text Citation: (Dahalan et al., 2020)

To Cite this Article: Dahalan, N. N. N., Kadir, N. A. A., \& Rahman, M. F. A. (2020). Role and Contribution of Malay Women's in Malaysia: An Overview. International Journal of Academic Research in Business and Social Sciences, 10(6), 118-126.

Copyright: (C) 2020 The Author(s)

Published by Human Resource Management Academic Research Society (www.hrmars.com)

This article is published under the Creative Commons Attribution (CC BY 4.0) license. Anyone may reproduce, distribute, translate and create derivative works of this article (for both commercial and non-commercial purposes), subject to full attribution to the original publication and authors. The full terms of this license may be seen at: http://creativecommons.org/licences/by/4.0/legalcode

Vol. 10, No. 6, 2020, Pg. 118 - 126

http://hrmars.com/index.php/pages/detail/IJARBSS

JOURNAL HOMEPAGE

Full Terms \& Conditions of access and use can be found at http://hrmars.com/index.php/pages/detail/publication-ethics 


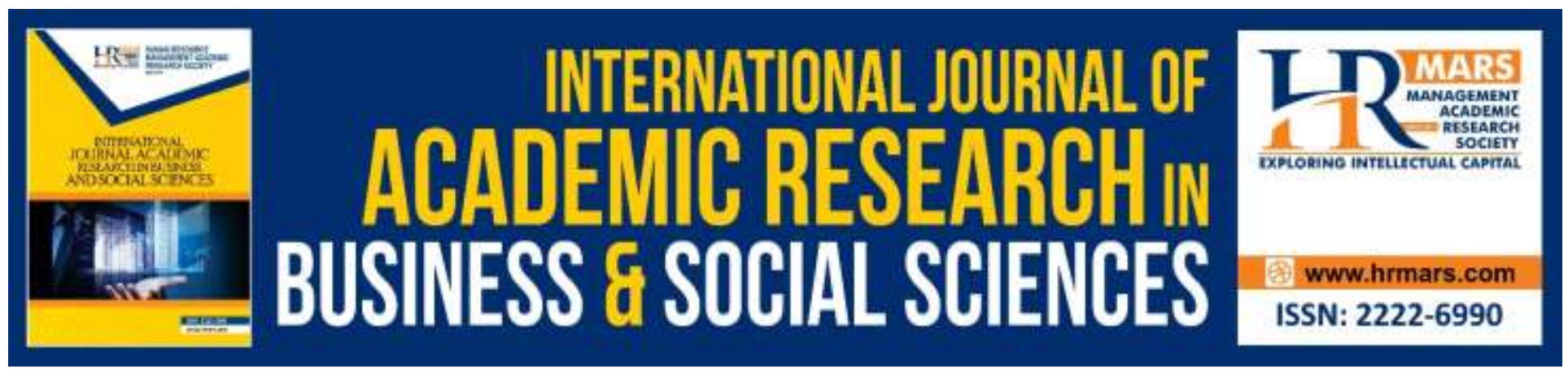

\title{
Role and Contribution of Malay Women's in Malaysia: An Overview
}

\author{
Nang Naemah Nik Dahalan ${ }^{1}$, Nor Adina Abdul Kadir ${ }^{1}$, Mohd Farhan \\ Abd Rahman² \\ ${ }^{1}$ Academy of Contemporary Islamic Studies (ACIS), MARA University of Technology (UiTM) Melaka \\ Branch, Alor Gajah Campus, 78000 Alor Gajah, Melaka, Malaysia, ${ }^{2}$ Academy of Contemporary \\ Islamic Studies (ACIS), MARA University of Technology (UiTM) Perak Branch, Seri Iskandar Campus, \\ 32610 Seri Iskandar, Perak, Malaysia
}

\begin{abstract}
Women represent nearly half of the population in Malaysia. Statistics issued by the Department of Statistics in 2018 showed that the population of men and women were 32.4 million which is 16.7 million are male and 15.7 million are female. Women should be given equal opportunity to pursue education. They represent an important human capital in a country. Nowadays, they're involve in various sectors such as economy, politics and social activities. Islam has brought a change that puts women in a proper position. This article will discuss the Malay Women, their role and impact that can develop and make a difference to Muslim women in Malaysia. Perception and confidence in the low position of women has been eroded. Women's awareness of the importance of education has brought progress to them.
\end{abstract}

Keywords: Malay Women, History of Education, Role and Contribution.

\section{Introduction}

An early education stages in Malaya is an informal education that focuses on the teaching of the Holy Quran, moral and spiritual formation. Regarding to Seng (1975), education for Malay children start early $18^{\text {th }}$ century where parents support their children with a sleeping mat and pillow, a cooking pot and a sack of rice. According to Bakar (1980), the previous school that exists does not focus on subject of reading, writing and counting but focuses on religious education. Miller (1968) also has mentioned that formal education for Malay children started when they were six years old. They learn Quran classes. Imams teach how to be polite, reciting prayers and reading al-Quran. This opinion is also amplified with Cheeseman $(1979,126)$ statement;

The first schools in Malaya were the Koran schools. These were possibly small groups of pupils in different part of the country, wherever there happened to be Muslim religious teachers. We are accustomed to hear scorn poured upon the parrot like repetition of the Koran. 
Essentially, in all Asian cultures, the education of the Quran is considered as formal education related to religion and the Malays mostly learn the teaching of the Quran (Stevenson, 1975). A traditional Malay education was primarily concerned with the transmission of Quranic teaching. However, this method of education is less effective because the students simply memorize the Quran and study Islam without being able to understand it. Education in the context of Islam is regarded as a process that involves the complete person, including the rational, spiritual, and social dimensions.

The objectives of this paper are to know the role and contribution of Malay women in early Islamic education. They are the main subject of this writing. They can be used together to add information or encourage further research. The role of women as individuals, wives, mothers, and members of society has shown how much they value the obligation to seek knowledge in Islam.

As we know, in Islam, women are given the right to pursue knowledge as were done by men. Women are encouraged to seek knowledge to become a knowledgeable and intelligent Muslim. Finally, the role and contribution of Islamic education can develop and make a difference to Muslim women. Islamic education is a major asset that must be available in all of the Muslim individuals.

\section{History of Early Education in Malaysia}

Education has a variety of meanings and definitions. There are several terms of education from the perspective of Arabic language. The word ta'lim from the root 'alima means to know, to perceive, to be aware and to learn which is used to represent knowledge being sought or imparted through instruction or teaching. Another word is tarbiyyah from the root raba means to increase, to grow and to rear implies a state of spiritual, soul and ethical nurturing in accordance with the will of God. An additional word is ta'dib, the root is aduba that give us a meaning to be cultured, refined, wellmannered that is to suggests a person's development and progress of sound social manners (Hamid, 2010).

According to Dewey (1966), education is the process of facilitating learning, or the acquisition of knowledge, skills, values, beliefs, and habits. There are a few types of education methods, which is storytelling, discussion, teaching, training, and directed research. Education frequently takes place under the guidance of educators; however, learners may also educate themselves.

For sure, based on the research of Hamid (2010), education provides a person the knowledge to differentiate and recognize the task, the ethical base to identify what to perform and act by time and the personal assets to carry out the tasks. The classification of Islamic education and knowledge can be divided to many views of scholars from the past and present such as Persian scholar Al-Ghazali (1111d.), Ibn Khaldun (1406d.) classified knowledge into 'ulum naqliyyah (revealed sciences) and 'ulum 'aqliyyah (rational sciences) which match up with "perennial knowledge" and "acquired knowledge" proposed by (Langgulung, 2008d.).

The Malay women in the traditional age only have an informal education at their home. The education given is appropriate with the needs of the day, which is to conduct household affairs and help their men to ease the burden of families (Twahir, 1995). At that time, there were some parents who refused to allow their children to go to school. This is because seeking an education is not important at that time (Muhamed, 1969). According to Sanusi (1955) education for girls are completely unacceptable, he states:

Maka bagi memberi pelajaran kepada kanak-kanak perempuan ini adalah suatu perkara yang susah kerana kebanyakan orang timur dan orang 
INTERNATIONAL JOURNAL OF ACADEMIC RESEARCH IN BUSINESS AND SOCIAL SCIENCES Vol. 10, No. 6, June, 2020, E-ISSN: 2222-6990 @ 2020 HRMARS

Melayu khasnya pada zaman dahulu tidak percaya yang perempuanperempuan patut diberi pelajaran sama seperti lelaki dan mereka tidak mahu melepaskan anak-anak perempuan mereka keluar rumah bercampur dengan lelaki.

[Then to give lessons to the girls is a problem that is difficult because most of Malays, in the old days do not believe that women should be given the same education as men, and they do not want to miss the girls they leave the house mingled with men.]

(Sanusi 1955, 52)

As we know, historical development of Islamic education in Malaysia is divided into two phases. The first phase deals with the situation before the arrival of the British to the Malay land. The second phase is after the British occupation and the influence and impact on Islamic education in Malaya (Ozay, 2010). Here, this article wants to focus on the first phase of the phase before the conquest of the British in Malaya.

Al-Quran lessons are highly preferred by the Malays. Imam also known as pious man or Pak Lebai will be organizing al-Quran classes. The basic education is like reading the Quran, praying and fasting. As early as age six to seven years, males and females will receive education. They are taught to literacy in the Quran, spell, and write in Jawi alphabet, memorizing and reciting the Quran (Noor, 2012). Thus, Malay children usually stay close to their place of study.

Every day, three lessons will be taught. An hour lasted at a time. One hour after the early dawn prayers, then after the mid-day devotions and the third after vespers. At other times, students will help their master in his house work and taking care his rice fields and orchards. Students will learn the verse and then repeat it in Arabic at every lesson began and ended. When these verses were memorized, they started to learn Jawi letters as a guide to reading the Qur'an. Through the memorization and the assistance given their master, students will be able to read the Qur'an and verses to perform prayer (Wilkinson, 1957).

In the beginning, the castle played a role as a center of learning and Islamic education. This was followed by surau, mosque, pondok and madrasah. This institution played an important role in the development of religious education. Pondok system is a continuation from the Islamic education in the houses, surau, mosques and palaces.

The state are known with pondok system are Kelantan, Terengganu and Kedah. Islamic education in Kelantan has started early. This proved by the existence of the earliest mosques such as Masjid Muhammadi and Masjid Kampung Laut 400 years ago. Meanwhile, Sheikh Abdul Halim is the earliest person delivers Islamic education in Kelantan (Noor, 2008). In Kedah, pondok institutions is one of the earliest education system. This institution located at Titi Gajah, Langgar, Pulau Pisang, Guar Kepayang, Kota Kuala Muda, Anak Bukit, Kodiang, Melele, Guar Cempedak, Tanjong Musang, Derga, Tobiar, Pantai Johor, dan Selarong Lalang (Bakar, 1980).

Terengganu is a state that produced many scholars are knowledgeable about the Islam. For example, Sheikh Abdul Malik Abdullah known as Tok Pulau Manis has founded a school at Pulau Manis. Other figures are Abdul Jamal b. Imam Yusuf, Haji Malik bin Isa, Muhammad b. Haji Abdul Malik and Syeikh Daud b. Abdullah al-Fatani.

Compared to the pondok institutions, madrasah institutions have more learning that is systematic, facilities, regular study time and structured learning curriculum. Kaum Muda is a founder 
INTERNATIONAL JOURNAL OF ACADEMIC RESEARCH IN BUSINESS AND SOCIAL SCIENCES

Vol. 10, No. 6, June, 2020, E-ISSN: 2222-6990 @ 2020 HRMARS

of madrasah institutions such as Madrasah al-lqbal, Singapore (1907), Al-Hadi, Malacca (1917) and Madrasah al-Mashoor, Penang (1919); (Hussin, 2004).

\section{Malay Women after the 1920s}

The level of education of the girls had started showing up in the 1920s. The Malays began to discuss education issues for their children, including for girls. The emergence of Malay students who received education from the Middle East with the idea of reform was seen as a starting point for education to women. In other words, education for Malay girls has existed, but it does not focus on reading, writing, calculating or giving skills in the work but devoting time to religious teaching. According to Bakar $(1980,6)$ :

Pendidikan rasmi untuk kanak-kanak Melayu bermula semasa ia berumur enam tahun di kelas quran. Di situ ia diajar oleh Imam tentang cara-cara bersopan santun, membaca dan mengaji al-quran.

[Formal education for children is starting when they was six years old in the Quran classes. They was taught by the Imam how to be polite, to read and study the Quran.]

According to Stevenson (1975), most cultures in Asia, education is associated with religion. Most of the Malay people are learning al- Quran that is considered as a formal education on that time and education in Malaya was begin with the establishment of al-Quran schools (Musa, 2005). The focus of education before the 1920s is for boys only. This is because the Malay parents have prejudiced and opposed their daughter's education. The Malay community sees places for girls only at home by learning basic skills such as cooking and sewing (Arifin, 1994). Girls usually did not finish their school. Parents will discontinue their daughter's schooling when they reach age of nine or ten years old to get married or help them at home. To clarify the above argument, the author highlight opinion of Chan $(1967,248)$. He states:

They thought a knowledge of reading and writing would promote letters and intrigue, they were nervous about allowing their girls to traverse streets or paths unaccompanied, the mothers dislike losing the service of their daughter and the self-satisfied parents thought they could pick up cookery and needlework as well at home as in school.

\section{The Role and Contribution of Malay Muslim Women}

Malay Muslim women played a big role in difference field of life. Islam gives dignity and elevation of the women by making them play multiple roles. This is emphasized in Islamic education for Muslim Malay woman.

Malay women as an individual

Women are an individual who serve as wives, mothers and community member (Karim 1982). From the standpoint of humanity, they are the same as men. They are entitled to be appreciated, giving their thoughts and get honourable position without discrimination (Kausar 2006). The Almighty Allah said: 
But the believers who do good deeds, whether men or women, shall enter Paradise. And not in the least injustice is done to them (or their reward reduced).

(An-Nisa', 4: 124)

Meanwhile, Hashim (2014) had written that one of the most important features that a woman needs as an individual is knowledge, patience and willing to sacrifice. This clearly shows that an important role of women and the needed of the community to engage women as individuals.

\section{Malay women as a Mother}

Islam commands us to respect and glorify the woman who called mother and cared for them. A mother plays a big role to educate and shaping their children at home. Therefore, mothers should give good examples to children and begin to form them with the fundamentals of Islamic principle since their childhood. As written in the Malay proverb 'early bird catches the worm'. A mother should also teach the children about the good manners in Islam. So, children need to be kind to their mothers. The Almighty Allah said:

And we enjoined man to show kindness to his parents. His mother bore him by bearing strain upon strain (from the beginning of her pregnancy till the end of the sucking period), and his weaning is two years. (Therefore) give thanks to me and to your parents, and (remember), to me is the final returning (so that all creatures shall be rewarded).

(Luqman, 31: 14)

\section{Malay Woman as a Wife}

A wife is responsible for managing the household while their husbands go out to work. They are cooking, tidying, washing and so on. They are as a companion and nearest to the husband. The Almighty Allah said:

And of his signs (to prove his might and mercy) is that he creates for you (o men) wives from among yourselves, that you might live in tranquility with them, and put love and kindness in your (husbands and wives) hearts. All those are signs (which make people realize the truth) for people who reflect.

(Ar-Rum, 30: 21)

\section{Malay women as a member of the Community}

In society, women's role is to assist in the welfare matters such as their involvement in spreading preach. Women have the right to actively involved in community. The almighty Allah said:

O men! Truly we have created you from a male and a female, and made you into nations and tribes that you might get to know (and be kind to) one another. The noblest of you in the sight of Allah is the one most deeply conscious of him among you (not in accordance with the nobility of lineage 
INTERNATIONAL JOURNAL OF ACADEMIC RESEARCH IN BUSINESS AND SOCIAL SCIENCES

Vol. 10, No. 6, June, 2020, E-ISSN: 2222-6990 @ 2020 HRMARS

or ethnicity). Truly Allah is most knowing, most aware (of your state and deeds).

(Al-Hujurat, 49: 13)

Malay Women as a Teachers and Educators

Education acquired by the Malay women proven through the changing role women in various aspects. This was mentioned by Kadir $(1997,11)$ also known as Munshi Abdullah:

At that time in Melaka, my grandmother became a teacher in the village of Pali, there are about two hundred of her students from men and women who study the Qur'an. Different groups to learn, some writing, some are learn Malay language.

Through the passage, the author can conclude that Malay women at that time were playing the role of a teacher or instructor.

6. Malay women as an economist

Islam allows women to work based on several requirements such as the absence of the husband, and the husband's inability and to work in positions that require the services of women such as doctors and so on. The Almighty Allah said:

Do not covet the favors by which Allah has exalted some of you above others (in respects of wealth, knowledge or position). (It has been decreed) that for men is a portion of what they earn, and for women is a portion of what they earn. (Thus, strive) and ask Allah of his bounty. Indeed, Allah has knowledge of all things.

(An-Nisa, 4: 32)

7. Malay women in the social sphere

The main purpose the creation of woman is to worship God, opposing evil and live according the laws of Allah. The Almighty Allah said:

And the believers, both men and women, are protecting friends one of another. They enjoin what is just and forbid what is evil; they attend to their prayers and pay the alms-tax, and they obey Allah and his messenger. On these, Allah will have mercy. Indeed Allah is al-mighty, most wise.

(At-Taubah, 9: 71)

\section{Conclusion}

In the traditional Malay family, especially for the young girls and women, they were always confined to their homes and taught the art of housewifery such as sewing, cooking food, cleaning clothes, and taking care of their younger sibling or children. Their lives are only at home as a wife, sister or daughter. Apart from household work, they also assist in rice fields and gardens. Nevertheless, the 
INTERNATIONAL JOURNAL OF ACADEMIC RESEARCH IN BUSINESS AND SOCIAL SCIENCES Vol. 10, No. 6, June, 2020, E-ISSN: 2222-6990 @ 2020 HRMARS

women are only given basic religious education informally at home or mosque such as learning alQuran, tauhid, feqah, akhlak, morals and so on.

In the advent of the Islamic society in Malaysia, Muslim Malay more focused and paying all of their attention on Islamic Education. Islam is highly regarded to those who are knowledgeable. The obligation of knowledge is demanded for all human beings. Islam does not abandon the rights of women to pursue knowledge. Therefore, a Malay woman who had previously only regarded as a daughter, wife and mother as well as an effective member of the community and actively contribute prosperity in the strength of the economy, science and medicine, education and politics in the country nowadays.

The important of Islamic education is mandatory for Malay Muslim not to simply reading, repeating and memorizing the words of Al-Qur'an without regard for understanding the meaning of passages in translation but to know and explore the reasons and philosophies behind the practice of Islamic restrictions, prohibitions and regulations. Education is a basic need and plays a very important role in the life of humanity. Education produce knowledge and information for people to understand something. There is no doubt that the goal and objective of Islamic education is to create and generate a good quality of life and be a knowledgeable human in this world.

\section{Corresponding Author}

Mohd Farhan Abd Rahman, Academy of Contemporary Islamic Studies (ACIS), MARA University of Technology (UiTM) Perak Branch, Seri Iskandar Campus, 32610 Seri Iskandar, Perak, Malaysia, farhan84@uitm.edu.my.

\section{References}

Arifin, J. (1994). Readings on Women and Development in Malaysia. Kuala Lumpur: Fakulti Ekonomi dan Pentadbiran Universiti Malaya.

Bakar, A. Z. A. (1980). Perkembangan Pendidikan di Semenanjung Malaysia: Zaman Sebelum Merdeka Hingga ke Zaman Sesudah Merdeka. Petaling Jaya: Penerbit Fajar Bakti Sdn. Bhd.

Chan, C. H. (1967). The Development of British Malaya 1986-1909. Kuala Lumpur: Oxford United Press.

Cheeseman, H. R. (1979). Education in Malaya 1900-1941. Journal of The Malaysian Historical Society, 22(1).

Dewey, J. (1966). Democracy and Education: An Introduction to The Philosophy of Education. New York: Free Press.

Hamid, A. F. A. (2010). Islamic Education in Malaysia. Singapore: S. Rajaratnam School of International Studies, Nanyang Technological University, Singapore.

Hashim, C. N. (2014). Dilema Wanita Bekerjaya: Cabaran dan Tanggungjawab. In Ilmuan Wanita Islam: Globalisasi dan Hak Wanita. Mahmud, M.W., Rahman, A.A.A. \& Hussin, A. (Eds.). Shah Alam: Persatuan Ulama' Malaysia.

Hussin, S. (2004). Pendidikan di Malaysia: Sejarah, Sistem dan Falsafah. Kuala Lumpur: Dewan Bahasa dan Pustaka.

Kadir, A. A. (1997). Hikayat Abdullah. Kuala Lumpur: Pustaka Antara.

Karim, N. S. (1982). Wanita Malaysia. Kuala Lumpur: Pustaka Ilmu Raya Sdn. Bhd.

Kausar, Z. (2006). Muslim Women at the Crossroads: The Right of Women in Islam and General Muslim Practices. Selangor: Thinker's Library Sdn. Bhd. 
INTERNATIONAL JOURNAL OF ACADEMIC RESEARCH IN BUSINESS AND SOCIAL SCIENCES

Vol. 10, No. 6, June, 2020, E-ISSN: 2222-6990 @ 2020 HRMARS

Miller, T. W. G. (1968). Education in South East Asia. Sydney: Ian Novak Publishing Co.

Muhamed, K. (1969). Wanita Melayu dan Pekerjaan. Dissertation University of Malaya, Malaysia.

Musa, M. (2005). Sejarah dan Sosioekonomi Wanita Melayu Kedah 1881-1963. Bandar Baru Bangi: Penerbit Universiti Kebangsaan Malaysia.

Noor, A. M. (2008). Perkembangan Pendidikan Islam di Kelantan. Malaysia dari Segi Sejarah, bil. 36.

Noor, A. M. (2012). Kesedaran Pendidikan Wanita Melayu Awal Abad ke-20. In Wanita dan Masyarakat. Eni, A.M. \& Ghani, R.A. (Eds.). Batu Pahat: UTHM.

Ozay, M. (2010). A Brief Overview: Breaking of Islamic Tradition of Education in Malaya. Proceeding International Conference on Leadership and Management in Islamic Education (ICLM 2010), University Technology of Malaysia, Skudai, Johor Bahru, Malaysia.

Sanusi, M. (1955). Sejarah Perkembangan Pelajaran Melayu. Pulau Pinang: Sinaran Bros.

Seng, P.L.F. (1975). Seeds of Separatism: Educational Policy In Malaya 1874-1940. Kuala Lumpur: Oxford Universiti Press.

Stevenson, R. (1975). Cultivators and Administrators: British Educational Policy towards the Malays 1875-1906. Kuala Lumpur: Oxford University Press.

Twahir, W. (1995). Ketokohan Wanita dalam Sejarah Pendidikan Islam Malaysia: Kajian Khusus di Negeri Kelantan. Dissertation University of Malaya, Malaysia.

Wilkinson, R. J. (1957). Malay Customs and Beliefs. Journal of the Malayan Branch Royal Asiatic Society, 30(4). 